ンに内蔵されたテレビチューナのチャネル切り替えだけで なく, ベースステーションに接続したビデオ機器を操作す るための画面リモコンを搭載している*1. ベースステーシ ヨンに接続されたリモコン信号発行部により, ビデオ機器 や衛星チューナ, AVアンプなどをクライアントからコント ロールして視聴することができる.リモコンを操作するこ とにより, 早送りや巻戻しなど再生操作に加え, 外出先か らビデオレコーダの録画予約などを行うことも可能である.

ベースステーションには無線LANアクセスポイント機能 が搭載されており, クライアントに合わせて $2.4 \mathrm{GHz}$ 帯の $\lceil\mathrm{IEEE} 802.11 \mathrm{~b} 」,\lceil\mathrm{IEEE} 802.11 \mathrm{~g} 」 ま た ， 5 \mathrm{GHz}$ 帯の 「IEEE802.11a」を切替えて使用できる（PCがクライアント の場合, 有線LANでの接続も可能).

ベースステーションとクライアントは1対1で機器認証さ れ，伝送されるデータは暗号化されている. ベースステー ションには4台までクライアントを登録することが可能で ある(同時に使用できるのは1台のみ).

\section{$2.2 \mathrm{PSP}^{\circledR}$}

PSP ${ }^{\circledR}$ は，無線LAN (IEEE802.11b) を標準装備し，アク セスポイントを経由してインターネット環境に接続, ゲー ムコンテンツやキャラクタのダウンロード, 遠く離れた友 人やオンラインコミュニティの仲間とのオンライン対戦な どが可能になるほか, アドホックモードでPSP ${ }^{\circledR}$ 同士を最 大16台まで直接接続し, 近距離でのオンラインゲームを行 うことができる*2.

$480 \times 272$ ドットの液晶ディスプレイを搭載し, 本体の画 面モード切替機能により映像を拡大して視聴することが可 能となっている。映像・音楽再生用コーデックとして, H.264 MPEG-4/AVC Main Profile Level3およびMPEG-4 Simple Profile/AAC-LCを搭載し，メディアプレーヤとし ての利用が可能となっている，バッテリーにはリチウムイ オン電池を採用し, ゲームソフトで 4 6時間, 動画では連 続4〜5時間の再生が可能である (UMD Video再生時).

\section{(3) システムの利用方法}

\section{1 初期設定}

初期の設定は, $\mathrm{PSP}^{\circledR}$ 上の画面案内にしたがって数回ク リックするだけで機器登録が完了する。これにより, 家の 中の無線LAN環境でテレビの視聴が可能になる．初期設定 の開始画面を図2に示す.

さらに，外出先から自宅で受信したテレビ放送を視聴す るための機能の初期設定を行うための仕組みがあり, $\mathrm{UPnP}$ 機能を搭載したルータと接続する場合には, $\mathrm{PSP}^{\circledR}$ 上 のブラウザの画面案内にしたがってネットワークの初期設

*1 $\mathrm{PSP}{ }^{\circledR}$ で「ケーションフリーベースステーション」の映像を再生す

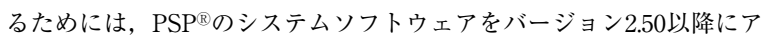
ップデートする必要がある.

*2 オンライン対戦の内容や接続可能台数などはゲームソフトウェアによ って異なる。

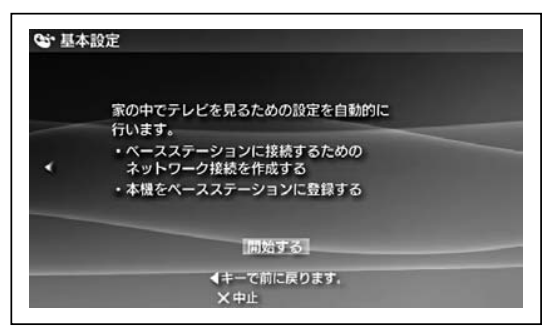

図2 初期設定画面
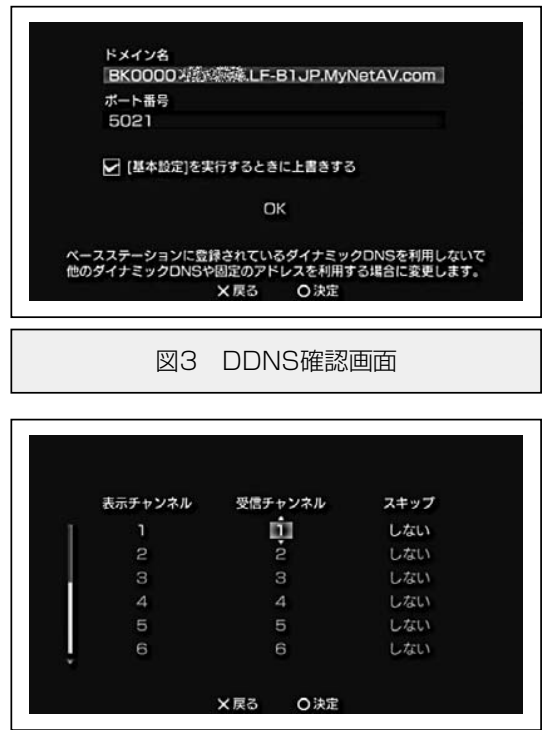

図4 日本向けチャネル設定画面

定が完了する.ベースステーションは, DDNSの自動通知 機能も搭載しており，インターネット経由のアクセスに対 して暗号化した映像を送信可能である．従来のシステムで は，ユーザがDDNSサービスの申し込みや設定をしなけれ ばならなかったが, 今回のシステムでは, 個々のベースス テーションに，あらかじめDDNSのURLを設定しサービス を提供することで，簡単設定と無料化を実現した.

ベースステーションは, UPnPに対応し，インターネッ ト経由での家庭内ルーティングを行う際に, UPnPに対応 したブロードバンドルータを設置してある環境においては 設定の簡易化・自動化が図られている. 図3は, 初期状態 で設定されたドメイン名を確認する画面である.

\section{2 チューナの設定}

ベースステーションに搭載されているチューナは, 地上 アナログ放送用のチューナであり, 日本向けと米国向けで 大きく仕様が異なる部分である. また，その他の国や地域 においても, 音声多重方式の違いやNTSC/PALの細かな 違いなど，歴史的な経緯でさまざまな仕様の違いがある.

図4は，日本向けのチャネル設定画面である．画面上に 表示されるチャネル番号と受信するチャネルの組合せはユ ーザが設定する。

図5は，米国向けのチャネル設定画面である（表示言語を 日本語にしてある). CATVのSTBなどベースステーション 内蔵でない外部のチューナを利用するケースに対応してい

(35) 695 


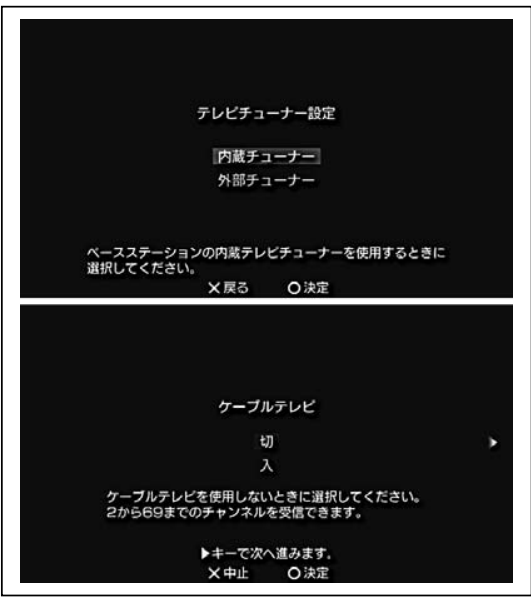

図5＼cjkstart米国向けチャネル設定画面

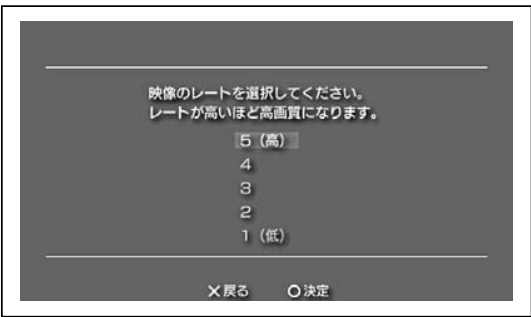

図6 レート設定画面

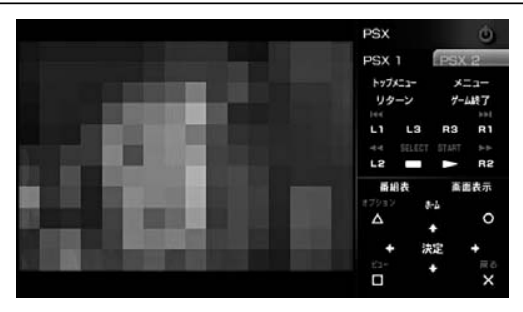

図7 リモコン画面

る、また，CATVを利用した場合と地上波を利用した場合 でチャネル周波数の設定を変えることが可能となっている.

\section{3 ストリーミング設定}

今回のシステムでは, 映像・音声コーデックとして MPEG-4 Simple Profile/AAC-LCを利用している. 今回の

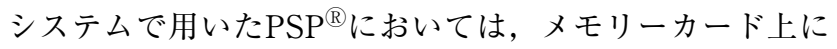
保存してあるMPEG-4動画ファイルの再生も可能となって おり, 映像・音声ストリームとしては, ほぼ同じ形式とな っている.

ベースステーションは, ルータ経由でブロードバンドに 接続するためのEthernet端子を装備している. ADSL, CATVインターネットなどの 高速回線に接続することが 可能である. 確保した帯域に合わせて最適な画像に自動調 整する (PCのクライアントのみ). インターネット回線の 環境に合わせて，より高画質な映像で見ることができる.

図6は，映像のビットレート設定画面である（音声のビッ トレートは固定). 回線状況に従い，ユーザが映像のビッ トレートを設定するレートを変更することで解像度やフ
レームレートが変化する.

\section{4 外部機器制御設定}

ベースステーションに内蔵したテレビのほか, ベースス テーションに接続したDVDレコーダなどの外部機器を「ソ フトウェアリモコン」で操作することができる.リモコン データはメモリーカード上に記録されるため, 将来的なア ップグレードも可能となっている.

図7は，リモコンを表示した状態である. 実際の機器のリ モコンからはボタン数は削減されているが, 比較的頻繁に 利用されると思われる機能が使用できるようになっている.

\section{4 む」すび}

今回のシステムは, 家庭用ゲーム機器・携帯ゲーム機器 の進化により, 新たに搭載されたメディア機能, 通信機能, 暗号化機能などを利用した，メディアプレーヤとしてのエ ンタテインメント性の一例である. さらに, 家庭のブロー ドバンド化と無線LANの普及により, 放送の地域格差を通 信を活かして解消し利用者の利便性の向上につなげるアプ リケーションが可能となった. 従来からあるアナログ放送 のテレビチューナや入力端子, 赤外線リモコンを利用する ことで，すでにユーザが持っている映像機器を活用するこ ともできる.

将来的な課題としては, (1) 高画質化, (2) 圥長性の縮小, (3) モビリティの向上, などが考えられる，家庭の通信環境 がブロードバンド化して来ているとはいえ, 比較的安価な ため普及しているADSLは非対称回線であり，上り方向の ビットレートはそれほど高くない場合も多い. 高効率なコ ーデックの採用により, ビットレートの削減と高画質化の 両立が望まれる。また，ストリーミングでは伝送状況の変 化に対応するためある程度のバッファリングが必要であ り，伝送開始時のキャッシングにより一定のタイムラグが 発生するので，とくにリモコンなどで機器制御を行った場 合にユーザに一瞬，違和感を与えることになる．改善のた めには，伝送速度や回線状況に応じた制御が必要と考えら れる。

さらに，より一層のユーザビリティを向上するためには, 無線LAN環境の普及が挙げられる. 現状ではホットスポッ トなどの外出先での無線LAN環境が都市部などに限定され ており，なかなか一般化していない. 現状の隽帯電話の通 信網は利用可能な地域が広いが, 動画のストリーミングに 使用する上では通信速度や通信料金の面で，現実的とは言 いがたい。当面の解決策として, 安価でカバレッジの広い 公衆無線LANサービスが期待される.

(2006年2月13日受付)

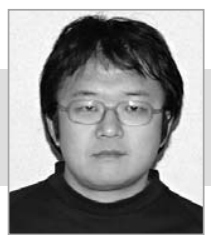
砮乫离輝忠之 1992 年, 早稲田大学理工学部電気 工学科卒業. 同年, ソニー（株）入社. 携帯オーデ イオプレーヤ, PDA, 携帯ゲーム機器などのマルチ メディア技術を用いたソフトウェアの開発に従事.

映像情報メディア学会誌 Vol. 60, No. 5 (2006) 